\title{
Learning Mathematics and Language through an Integrated Approach in Preschool Education
}

\author{
Sanja M. Maričić \\ University of Kragujevac \\ sanjamaricic1o@gmail.com \\ Mirjana M. Stakić \\ University of Kragujevac \\ mirjanastakico73@gmail.com
}

\begin{abstract}
The initial attitude in this paper argues that learning at preschool age should be characterised by a holistic approach which integrates different areas of knowledge. In this context, authors draw special attention to the importance of integrating language development and preschool mathematics education by means of literature for children. In the theoretical section, the authors define their goals - to determine the extent to which preschool teachers integrate language development and development of mathematical concepts, to learn which literary form is used most frequently as an integrative element and to determine the presence of integration in each content area of preschool mathematics education. Results show that preschool teachers most commonly integrate activities related to language development and mathematics, that the most frequently used integrative element is the prose and poetic text, and that literary content for children is commonly used as scaffolding to help children develop the concept of number and set.
\end{abstract}

Keywords: preschool education, integration, mathematics education, language development, child

\section{Introduction}

The period of preschool education is a very important period in the life of every individual, and the basics of learning laid out in this period are observed as the foundation for lifelong learning (Organisation for Economic CoOperation and Development 2006). Learning and development in preschool education are characterised by a holistic approach which 'integrates different areas of knowledge, thus uniting the cognitive, social, physical, emotional, cultural and spiritual aspect of child development' (Stakić and Maričić 2018, 369). 'Learning and teaching represent a comprehensive process seamlessly integrated in the context of everyday life' (Pavlović Breneselović and Krnjaja 
$2017,9)$. Preschool program argues that 'a child reacts with his/her whole being, and their intellectual, emotional, sensomotoric, social and speech development are interwoven and dependent on each other' (Pravilnik o osnovama programa predškolskog vaspitanja i obrazovanja 2018, 5).

Researches of preschool children's learning and development 'point to the fact that children cannot learn in the isolated subject disciplines, and that successful development of elementary mathematical concepts cannot occur if they are isolated in special learning situations' (Maričić, Stakić, and Malinović-Jovanović 2018, 632). Hence the decisive role of preschool teachers is to 'prepare and ensure the stimulating environment in order to give children the possibility for learning through touch, movement, sight and hearing' (Novaković 2015, 154). When developing their program, preschool teachers are encouraged to focus on 'creating learning opportunities as an integrated experience for the child, concentrating on things he does (action) and experiences (relationships), instead of focusing on preplanned individual activities based on development aspects, content areas or isolated teaching content' (Pravilnik o osnovama programa predškolskog vaspitanja i obrazovanja 2018, 35-36). The child will experience learning as an element integrated in his/her everyday life context, and through exchange with his environment. Learning is a cooperative and communication-based process (Pavlović Breneselović and Krnjaja 2017, 22).

When it comes to preschool mathematics education, recommendations stating that the process of mathematical learning should be integrated with other areas of knowledge at an early age reverberate even louder. This makes sense, given the abstract quality of mathematical concepts on the one hand, and the characteristics of the thinking process of children on the other hand. The National Association for the Education of Young Children (NAEYC) and the National Council of Teachers of Mathematics (NCTM) also recommend that we should 'integrate mathematics with other activities and other activities with mathematics' (National Association for the Education of Young Children and National Council of Teachers of Mathematics 2002, 7). Therefore, authors of this paper would like to draw attention to the importance of integrating preschool mathematics education and language development in teaching practice by means of literary content for children.

Our starting point is the idea that the development of mathematical concepts from an early age 'must be placed in a realistic context, the child must be movitated to participate in learning, and the learning process must be prompted by internal impulses of the child' (Stakić and Maričić 2018, 370), but also by the ideas of Vygotsky (Vigotski 1977) and his associates who ob- 
served learning as a social process occurring in interaction with others, in socially constructed situations where language plays a central role. 'Thinking, learning and language are interwoven. Children use oral, written and visual language to convey ideas, thoughts, emotions, values and beliefs, to learn to understand themselves and others, and to analyse their own learning process and thinking processes' (Pavlović Breneselović and Krnjaja 2017, 23).

The process of preschool mathematics education is characterised by numerous idiosynchrasies. A child of preschool age is a unique recipient and learning at this age greatly differs from the learning process of adults. Children learn on their own in situations which make sense to them, when they are prompted by intrinsic motivation to learn, and when learning is familiar, based on their personal experience and needs. These are situations in which mathematical context is pushed in the background, and learning is placed in a context familiar and interesting to the child, and when it comprises activities the child is willing to participate in. Both the National Association for the Education of Young Children and the National Council of Teachers of Mathematics emphasise the importance of 'weaving mathematics into children's experiences with literature, language, science, social studies, art, movement, music, and all parts of the classroom environment' (National Association for the Education of Young Children and National Council of Teachers of Mathematics 2002, 7). Children's literature creates such a context to a great extent, because it represents the basic content for language development activities, and in terms of mathematics education, it represents an integrative element which creates a foundation and a realistic learning context.

Numerous studies indicate there is a connection between mathematics and language development in preschool period, where both subjects contribute to child's development (Ojose 2008; Purpura et al. 2011; Welsh et al. 2010). Authors emphasise that this way, we get meaningful and authentic learning (Clements, Sarama, and DiBiase 2003; Kilpatrick, Swafford, and Findell 2001), and that this teaching strategy helps students use mathematics to connect to their own lives each day (Pomykal Franz and Pope 2005). An integrated approach to learning is in harmony with the idea of holistic preschool education. The teacher uses literary content to spontaneously create conditions for associating learning with the child's personal experience, to link practical activities with activities occurring in the realm of the abstract, thus ensuring a spontaneous transition from concrete, realistic concepts to abstractions and generalisations required by the very nature of mathematics. Mathematics is presented to children using a language they understand. The language is visualised through images generated by the literary text, 
all of which helps children understand mathematical ideas and concepts. In addition, literary content for children also creates a context for solving problems which are then translated to the domain of mathematics, whereas children are additionally encouraged to actively participate in problem solving, because mathematical context is pushed in the background. This manner of organising activities in preschool education allows children to experience mathematics as part of their everyday lives, not just as an abstract and isolated subject, which helps stimulate their interest in mathematics and their understanding of it. Literary content for children motivates students to learn by providing a meaningful context for mathematics, celebrates mathematics as a language, demonstrates that mathematics develops out of human experiences, fosters the development of number sense and integrates mathematics into other curriculum areas (Whitin and Wilde 1992). It represents the 'basis' for activities directed towards speech development in preschool children and, on the other hand, provides the basis for the development of abstract mathematical concepts in preschool education (Stakić and Maričić 2019, 185). This way, learning mathematics and learning language merge together, and their content and activities continuously permeate each other.

Reading can be comprehended as a problem-solving and constructive process, meaning that integrating mathematics and literature could be effective: integration not only develops mathematical skills but literacy, mathematical language, and problem solving as well (Wiburne and Napoli 2008 in Wikholm and Aerila 2016, 565). A child enjoys a literary text, identifies with a hero, and often becomes a creator itself, continuing the illusion of a depicted reality in its imagination (Stakić and Maričić 2019, 185).

Thematic structure of children's literature is close to the needs and interests of a preschool child, so any literary form (poetry, prose, play, short literary forms) can be used as an integrative element. The choice of literary form, as well as literary content depends primarily on the goals we want to achieve in each area of knowledge: language development and mathematics education. The same text plays a different role in each content area. Activities in this process are intertwined, first they occur separately, and then they merge together. This way, children develop language skills in addition to mathematical skills: speech sounds are correctly articulated and discriminated, child's active vocabulary is enriched and expanded, and finally, the child's sentence is developed and corrected. This way, reality portrayed by literary content is visualised through specific didactic material and placed in a realistic learning environment. Children readily participate in such activities and acquire 
knowledge on their own. They do not distinguish between the subjective and the objective, the real and fantasy world co-exist on the same plane. This is why children are so attracted to fairy tales, because they depict the world exactly as children imagine it (Purić and Maričić 2010).

For example, analysing the fairy tale Goldilocks and the Three Bears as part of language development helps develop the skills of listening, speaking, retelling, description, vocabulary enrichment, etc. When applied to mathematics education, the said fairy tale creates a realistic and rich context which, when coupled with didactic material, creates a basis for developing the concept of number three, but also proportional relationships (big-small), seriation by size, etc. There are three bears, three chairs, three tables, etc. in the fairy tale. These elements are presented with by means of didactic material and they help children create a clear mental image of number three. In addition, the fairy tale can be used as a starting point for introducing proportional relationships. Three bears are of different size, as well as their beds, chairs, food bowls, clothes, etc. Children will identify these separate elements and compare them to each other.

Numerous studies outline the benefits of this type of integrated mathematics education which utilises literary content for children in preschool education (Welsh et al. 2010; Ojose 2008; Purpura et al. 2011; Rosen and Hoffman 2009; Skoumpourdi and Mpakopoulou 2011; Van den Heuvel-Panhuizen and Elia 2011; Van den Heuvel-Panhuizen, Elia, and Robitzch 2016). Even a picture book as the first book in the child's life offers countless possibilities for integrated teaching aimed at developing language and mathematical skills. The fact these books contain little to no text helps teachers motivate their students to upgrade and complement the image/images by inventing a story of their own, which stimulates and channels their language development. In addition, cognitive context of the picture book is familiar to the child, so he will have no trouble identifying with it.

This way, the child will learn spontaneously, because reading the text from a picture book represents a natural continuation of learning through play which was a dominant teaching method during preschool education (Maričićm Maksimović, and Stakić 2018, 400). On the other hand, when it comes to the development of mathematical skills, research results confirm a threemonth reading program which uses picture books containing mathematical content has positive effects on the improvement of children's math performance even when no additional mathematical activities are involved (Van den Heuvel-Panhuizen, Elia, and Robitzch 2016).

Given the opinion stated above, i.e. that all literary forms can be used 
as an integrative element when teaching preschool children, and that the choice of a specific form is determined by the specific goals a teacher wants to acoomplish in each content area (language development and development of mathematical concepts), we wanted to examine the actual situation in preschool education. We examined the extent to which preschool teachers integrate language development and development of mathematical concepts, which literary form is used most frequently as an integrative element and the presence of integration in each content area of preschool mathematics education.

\section{Methodological Framework}

Our survey was conducted in May 2018 on a sample $(N=200)$ chosen from the population of preschool teachers working in preschool institutions in the Republic of Serbia. The sample had characteristics of a random sample. The preschool teachers have voluntarily agreed to the survey. Our survey encompassed preschool teachers with different professional experience, different level of education and teachers working in different models of education ( $A$ - open model of education, $B$ - closed model of education). The highest percentage of respondents have between 11 and 20, and 21 to 30 years of experience ( $32 \%$ each), followed by preschool teachers with less than 10 years of experience (20\%).

The lowest percentage of respondents have over 30 years of experience (16\%). Only $30 \%$ of all respondents have a degree of a vocational college, whereas $70 \%$ of the respondents have a university degree. $77 \%$ of the respondents use model B, whereas only $23 \%$ use model $A$.

Our survey is based on a descriptive method. The data necessary for the survey were collected through interviewing. We designed a closed-ended questionnaire. Teachers responded by selecting an answer that best expressed their opinion among several available answers. The survey was anonymous to ensure sincerity and avoid desirable answers. The value of the Cronbach's alpha coefficient (0.897) indicates realiability of instruments used and justifies their acceptability.

The following characteristics of preschool teachers comprise the independent variable: professional experience (less than 10 years, between 11 and 20 years, between 21 and 30 years, more than 30 years) and level of education (vocational college degree, university degree). The data were processed using the IBM SPSS Statistics 23 statistical software. Measures of descriptive statistics used include frequencies and percenteges. We also used the chisquare test and $F$-test as analysis methods enabling statistical reasoning. 
Table 1 Descriptive Statistics: Integrating Preschool Mathematics Activities with Other Areas of Knowledge

\begin{tabular}{lrrrrrrr}
\hline Areas of knowledge & 1 & 2 & 3 & 4 & 5 & $M$ & $S D$ \\
\hline Language development & 90 & 74 & 20 & $\begin{array}{r}10 \\
(45 \%)\end{array}$ & 6 & 1.84 & 1.002 \\
& 82 & 52 & 40 & 14 & 12 & 2.11 & 1.197 \\
\hline Getting to know one's & $(10 \%)$ & $(5 \%)$ & $(3 \%)$ & & \\
environment & $81 \%)$ & $(26 \%)$ & $(20 \%)$ & $(7 \%)$ & $(6 \%)$ & & \\
\hline Music education & 24 & 40 & 66 & 62 & 3.75 & 1.140 \\
& $(4 \%)$ & $(12 \%)$ & $(20 \%)$ & $(33 \%)$ & $(31 \%)$ & & \\
\hline Art education & 2 & 22 & 46 & 68 & 62 & 3.83 & 1.025 \\
\hline Physical education & $(1 \%)$ & $(11 \%)$ & $(23 \%)$ & $(34 \%)$ & $(31 \%)$ & & \\
\hline
\end{tabular}

\section{Results and Discussion}

The first research task was to determine the extent to which preschool teachers integrate learning activities within preschool mathematics education and language development with regard to other areas of knowledge. Preschool teachers are on a scale of 1 (highest) to 5 (lowest) evaluated the degree of integration learning activities of mathematical educational and other areas of knowledge. Results show that preschool teachers most frequently integrate activities related to preschool mathematics education with language development ( $M=1.84)$, followed by getting to know one's environment $(M=$ 2.11) (table 1). The third most frequent form of integration is integration with physical education $(M=3.47)$, whereas activities within mathematics education are seldom integrated with activities related to music education $(M=3.75)$ and art education $(M=3.83)$.

Results also validate our theoretical assumptions on the role and importance of integrating activities of mathematics education and language development. This means teachers are able to recognise and understand the connection between language development and mathematics education, and behave accordingly. Another proof of the validity of this practice in preschool mathematics education is the fact that, besides integrating activities related to mathematical content, preschool teachers also frequently integrate activities aimed at becoming familiar with one's environment. Through literary content, teachers create a basis for familiarising children with mathematical concepts, and by including activities aimed at familiarising oneself with one's environment, they link mathematics to real life and allow children to apply mathematical knowledge in practice. This way, they bridge the gap between 
Table 2 F-test: Differences in Teacher Attitudes on Integrated Teaching in Preschool Education with Regard to Professional Experience, Level of Education and Model of Preschool Education

\begin{tabular}{|c|c|c|c|}
\hline Areas of knowledge & $\begin{array}{l}\text { Professional } \\
\text { experience }\end{array}$ & Level of education & $\begin{array}{l}\text { Model of preschool } \\
\text { education }\end{array}$ \\
\hline Language development & $\begin{array}{l}F(3,196)=0.591 \\
p=0.623\end{array}$ & $\begin{array}{l}F(1,198)=1.286 \\
p=0.260\end{array}$ & $\begin{array}{l}F(1,198)=1.050 \\
p=0.308\end{array}$ \\
\hline $\begin{array}{l}\text { Getting to know one's } \\
\text { environment }\end{array}$ & $\begin{array}{l}F(3,196)=2.142 \\
p=0.100\end{array}$ & $\begin{array}{l}F(1,198)=1.081 \\
p=0.301\end{array}$ & $\begin{array}{l}F(1,198)=0.489 \\
p=0.486\end{array}$ \\
\hline Music education & $\begin{array}{l}F(3,196)=1.693 \\
p=0.174\end{array}$ & $\begin{array}{l}F(1,198)=0.082 \\
p=0,776\end{array}$ & $\begin{array}{l}F(1,198)=1.708 \\
p=0,194\end{array}$ \\
\hline Art education & $\begin{array}{l}F(3,196)=1.539 \\
p=0.209\end{array}$ & $\begin{array}{l}F(1,198)=0.687 \\
p=0,409\end{array}$ & $\begin{array}{l}F(1,198)=0.194 \\
p=0,660\end{array}$ \\
\hline Physical education & $\begin{array}{l}F(3,196)=0.218 \\
p=0.884\end{array}$ & $\begin{array}{l}F(1,198)=0.102 \\
p=0.750\end{array}$ & $\begin{array}{l}F(1,198)=5.253 \\
p=0.024\end{array}$ \\
\hline
\end{tabular}

children's interests and mathematics, making mathematics more familiar and understandable to the child's outlook on the world, but also creating a strong bond between mathematics and one's actual environment, which helps children understand this science and recognise ways to implement it in everyday life.

Analysing the opinions of preschool teachers with regard to the independent variable (professional experience, level of education and model of education) (table 2), we determined teachers are united in their attitudes on the integration of activities aimed at developing mathematical concepts and activities related to other areas of knowledge. The only statistically significant differences exist between teachers who work in different models of education $(F(1,198)=5.253 ; p=0.024)$, and they are reflected in their opinions about the frequency of integrating activities related to physical education and activities aimed at developing mathematical concepts. Teachers working by model $A$ integrate activities related to physical education with activities aimed at developing mathematical concepts more frequently than teachers working by model $\mathrm{B}$.

Results we obtained are the best proof preschool teachers share the opinion on the importance of integration between language development and elementary mathematical concepts, and the proof they actually organise and undertake activities aimed at integrating these two areas of knowledge.

We wanted to examine which literary forms are used most frequently for developing mathematical concepts. We offered the following literary forms in the questionnaire: poetic text, prose text (stories, fairy tales, fables, etc.), short 
Table 3 Descriptive Statistics: Presence of Literary Forms in Mathematical Concept Development

\begin{tabular}{lrrrrrr}
\hline Literary forms & 1 & 2 & 3 & 4 & $M$ & $S D$ \\
\hline Poetic text & 28 & 58 & 62 & 52 & 2.69 & 1.012 \\
& $(14 \%)$ & $(29 \%)$ & $(31 \%)$ & $(26 \%)$ & & \\
\hline Prose text & 100 & 46 & 48 & 6 & 1.80 & .910 \\
& $(50 \%)$ & $(23 \%)$ & $(24 \%)$ & $(3 \%)$ & & \\
\hline Short literary forms & 38 & 44 & 42 & 76 & 2.78 & 1.151 \\
& $(19 \%)$ & $(22 \%)$ & $(21 \%)$ & $(38 \%)$ & & \\
\hline Drama text & 34 & 52 & 48 & 66 & 2.73 & 1.100 \\
& $(17 \%)$ & $(26 \%)$ & $(24 \%)$ & $(33 \%)$ & & \\
\hline
\end{tabular}

Table 4 F test: Attitudes of Preschool Teachers about Literary Forms Most Frequently Used in the Development of Mathematical Concepts with Regard to Professional Experience, Level of Education and Model of Education Used

\begin{tabular}{llll}
\hline Literary forms & $\begin{array}{l}\text { Professional } \\
\text { experience }\end{array}$ & Level of education & $\begin{array}{l}\text { Model of preschool } \\
\text { education }\end{array}$ \\
\hline Poetic text & $F(3,196)=0.179$ & $F(1,198)=0.634$ & $F(1,198)=0.538$ \\
& $p=0.910$ & $p=0.428$ & $p=0.465$ \\
\hline Prose text & $F(3,196)=1.197$ & $F(1,198)=0.000$ & $F(1,198)=1.324$ \\
& $p=0.315$ & $p=1.000$ & $p=0.253$ \\
\hline Short literary forms & $F(3,196)=1.184$ & $F(1,198)=4.168$ & $F(1,198)=1.092$ \\
& $p=0.320$ & $p=0.044$ & $p=0.299$ \\
\hline Drama text & $F(3,196)=0.495$ & $F(1,198)=1.892$ & $F(1,198)=0.669$ \\
& $p=0.687$ & $p=0.172$ & $p=0.416$ \\
\hline
\end{tabular}

literary forms (riddles, tongue twisters, counting rhymes, etc.) and drama text, ranked from 1 (highest ranking) to 4 (lowest ranking) by the frequency with which a literary form appears in mathematical concept development.

Results show that the most frequently used literary forms in preschool mathematics education are prose text $(M=1.80)$, followed by poetic text ( $M$ $=2.69)$, drama text $(M=2.73)$, and finally, short literary forms $(M=2.73)$.

Statistical analysis shows that preschool teachers with different professional experience, level of education and working by different models are united in their outlook and that there are no statistically significant differences in their attitudes (table 4).

The data show teachers most frequently use prose texts, including stories, fairy tales, fables, etc. for mathematical concept development. This makes sense, given the nature of children on the one hand, and the content of prose texts for children on the other hand. The subject matter of prose texts is familiar and relatable to children. 'Apart from the world of childhood and differ- 
Table 5 Descriptive Statistics: Implementation of Literary Content for Children in Different Areas of Preschool Mathematics Education

\begin{tabular}{lrrrrrrr}
\hline Areas & 1 & 2 & 3 & 4 & 5 & $M$ & $S D$ \\
\hline Number & 76 & 58 & 30 & 18 & 18 & 2.22 & 1.292 \\
& $(38.0 \%)$ & $(29.0 \%)$ & $(15.0 \%)$ & $(9.0 \%)$ & $(9.0 \%)$ & & \\
\hline Set & 40 & 60 & 60 & 22 & 18 & 2.59 & 1.190 \\
& $(20.0 \%)$ & $(30.0 \%)$ & $(30.0 \%)$ & $(11.0 \%)$ & $(9.0 \%)$ & & \\
\hline Geometry & 14 & 30 & 46 & 60 & 50 & 3.51 & 1.219 \\
& $(7.0 \%)$ & $(15.0 \%)$ & $(23.0 \%)$ & $(30.0 \%)$ & $(25.0 \%)$ & & \\
\hline Spatial relations & 64 & 26 & 38 & 52 & 20 & 2.69 & 1.412 \\
& $(32.0 \%)$ & $(13.0 \%)$ & $(19.0 \%)$ & $(26.0 \%)$ & $(10.0 \%)$ & & \\
\hline Measurements & 6 & 26 & 26 & 48 & 94 & 3.99 & 1.185 \\
& $(3.0 \%)$ & $(13.0 \%)$ & $(13.0 \%)$ & $(24.0 \%)$ & $(47.0 \%)$ & & \\
\hline
\end{tabular}

ent life events, human and children's feelings, love, kindness, play, friendship, human altruism and humanity, love for parents and animals, imaginative and picturesque events, cheerful humour and painted scenes, flora and fauna, fictional worlds, sympathy and the first secret, are some of the common themes of children's literature' (Stakić 2014, 245). The topics mentioned above create a picturesque world a child can envision and complement through imagination, a place he/she can escape into, or identify with the heroes. From the standpoint of language, this contributes to the development of all linguistic elements, i. e. phonetic, morphological, lexical and syntactic. All of the above also has a positive psychological effect on children, because a first contact with prose texts occurs in an environment where the child feels safe and loved, in the family when parents read fairy tales to their children. This also represents the first spontaneous effort toward language development. Research studies also indicate that reading books together provides the first context in which children and their parents can participate in mathematical conversations (Anderson, Anderson, and Shapiro 2005)

The goal of the third task was to examine areas of preschool mathematics education where the literary content for children was used most frequently. The question for preschool teachers was defined as following - In what areas of preschool mathematics education do you most frequently integrate literary content for children? - and the available answers were the following: numbers, sets, geometry, relations, measurements, ranked from 1 (most frequently) to 5 (least frequently) in descending order. Based on this task, we set up a hypothesis: preschool teachers implement literary content for children most frequently to help children develop the concept of number.

The data we obtained show that teachers commonly use literary content 
Table 6 F test: Teachers' Attitudes on Content Integrated with Other Areas of Knowledge with Regard to their Professional Experience, Level of Education and Model of Education Used

\begin{tabular}{llll}
\hline Areas & $\begin{array}{l}\text { Professional } \\
\text { experience }\end{array}$ & Level of education & $\begin{array}{l}\text { Model of preschool } \\
\text { education }\end{array}$ \\
\hline Number & $\begin{array}{l}F(3,196)=0.407 \\
p=0.748\end{array}$ & $\begin{array}{l}F(1,198)=2.873 \\
p=0.093\end{array}$ & $\begin{array}{l}F(1,198)=0.004 \\
p=0.950\end{array}$ \\
\hline Set & $F(3,196)=0.354$ & $F(1,198)=0.002$ & $\begin{array}{l}F(1,198)=2.520 \\
p=0.116\end{array}$ \\
& $p=0.787$ & $p=0.964$ & $F(1,198)=2.639$ \\
\hline Geometry & $F(3,196)=1.963$ & $F(1,198)=1.077$ & $p=0.107$ \\
\hline Spatial relations & $p=0.125$ & $p=0.782$ & $F(1,198)=1.809$ \\
& $F(3,196)=0.661$ & $F(1,198)=0.878$ & $p=0.182$ \\
\hline Measurements & $p=0.578$ & $p=0.351$ & $F(1,198)=1.091$ \\
& $F(3,196)=0.155$ & $F(1,198)=1.400$ & $p=0.299$ \\
\hline
\end{tabular}

for children as scaffolding to help children develop the concept of number, $(M=2.22)$, to develop the concept of set $(M=2.59)$, and spatial relations (size and position) ( $M=2.69)$. Literary content is least frequently used to develop concepts related to geometry $(M=3.51)$ and measurements $(M=3.99)$ (table 5).

The fact that teachers most frequently use literary content to develop the concept of number makes perfect sense. Numbers from 1 to 10 appear quite often in preschool mathematics education in comparison to other content. In addition, there are numerous elements in children's literature that can be used to develop and understand the concept of numbers, their structure, position in a sequence, relationship with other numbers. Picture books can be used for this purpose because they are filled with sets whose cardinal number represents a natural number, poetic texts easy to memorise, stories where we repeatedly encounter a set whose cardinal number is the number children are trying to develop, short literary forms which teach children to count and name numbers, or fairy tales which have symbolic numbers that repeat over and over again (e.g. seven towers, seven seas, seven mountains, seven dwarves, seven little goats, etc.). From the aspect of language development, children name the concept of number within the context of a sentence, as the most common unit of communication; they use the concept in its different morphological forms and lexical combinations with other word classes, thus spontaneously adopting congruence and correct word usage in everyday communication.

The second most common usage of literary content in preschool mathematics education is to develop the basic elements of the set theory (element, 
membership), but also relations between sets. Literary content for children is least used for developing geometric concepts, the concept of measurements and for familiarising children with units of measurement, which stems from the fact that developing these concepts relies on practical activities, i. e. utilisation of didactic materials and tools that can be found in the immediate environment, so their models are already available to children and don't require additional context.

Analysis of teachers' opinions with regard to their professional experience, level of education and model of education used shows there are no statistically significant differences among these groups. Looking at table 6 , we can see there are no statistically significant differences in preschool teachers' attitudes with regard to the independent variables.

\section{Conclusion}

Results of our survey show that in preschool practice in Serbia, activities aimed at mathematics education are most frequently integrated with activities aimed at speech and language development of preschool children. Preschool teachers utilise literary content for children for this purpose, primarily short prose and poetic texts. Their suitability stems from their content which is interesting and familiar to children, but at the same time packed with mathematical examples conducive to the development of the concept of number, concept of set and spatial relations. In addition, these literary forms with integrated mathematical concepts help in language development through retelling, descriptions, dramatisation, etc, all of which is aimed at improving children's comprehension. Children practice correct articulation and discrimination of speech sounds, enrich and expand their vocabulary, and practice correct usage of morphological forms of word on lexical combinations realised within a sentence. At the same time, they enrich and develop their sentence, gradually increasing the number of sentence elements. It is a teacher's duty to devise and plan these activities in detail, to find suitable literary texts that can be used as the starting point in the integration of mathematics education and language development. Despite the fact many literary texts could be used for this purpose, there are other criteria they need to meet, e.g. they need to be suitable for preschool age and they need to meet the aesthetic criteria. This is why we recommend experts involved in the integration of language development and mathematics education should make a selection of appropriate literary texts containing teaching methods and methodology-related instructions that would greatly facilitate the efforts of preschool teachers. 


\section{References}

Anderson, A., J. Anderson, and J. Shapiro. 2005. 'Supporting Multiple Literacies: Parents' and Children's Mathematical Talk within Storybook Reading.' Mathematics Education Research Journal 16 (3): 5-26.

Clements, H. D., J. Sarama, and A. DiBiase. 2003. Engaging Young Children in Mathematics: Findings of the 2000 National Conference on Standards for Preschool and Kindergarten Mathematics Education. Mahwah, NJ: Lawrence Erlbaum.

Kilpatrick, J., J. Swafford, and B. Findell. 2001. Adding It up: Helping Children Learn Mathematics. Washington, DC: National Academy Press.

Maričić, S., M. Stakić, and N. Malinović-Jovanović. 2018. 'The Role of Literary Content for Children in Preschool Mathematics Education.' Eurasia Journal of Mathematics, Science \& Technology Education 4 (2): 631-642.

Maričić, S., J. Maksimović, and M. Stakić. 2018. 'Use of the Picture Book in Teaching Mathematics and Serbian Language to Children with Learning Disabilities.' In Oblikovanje inovativnih učnih okolij, edited by T. Štemberger, S. Čotar Konrad, S. Rutar, and A. Žakelj, 395-413. Koper: Založba Univerze na Primorskem.

National Association for the Education of Young Children and National Council of Teachers of Mathematics. 2002. 'Early Childhood Mathematics: Promoting Good Beginnings.' https://www.naeyc.org/files/naeyc/file/positions/ psmath.pdf

Novaković, S. 2015. 'Preschool Teacher's Role in the Art Activities of Early and Preschool Age Children.' Croatian Journal of Education 17 (1): 153-163.

Ojose, B. 2008. 'Applying Piaget's Theory of Cognitive Development to Math Instruction.' The Mathematics Educator 18:26-30.

Pravilnik o osnovama programa predškolskog vaspitanja i obrazovanja. 2018. http://zuov.gov.rs/wp-content/uploads/2018/10/Године-узлета.pdf

Organisation for Economic Co-operation and Development. 2006. Starting Strong II: Early Childhood Education and Care. Pariz: Organisation for Economic Co-operation and Development.

Pavlović Breneselović, D., and Ž. Krnjaja. 2017. Kaleidoskop: osnove diversifikovanih programa predškolskog vaspitanja i obrazovanja. Beograd: Institut za pedagogiju i andragogiju.

Pomykal Franz, D., and M. Pope. 2005. 'Using Children's Stories in Secondary Mathematics.' American Secondary Education 33 (2): 21-28.

Purić, D., and S. Maričić. 2010. 'Savremenost i funkcionalnost bajke u razvoju govora i početnih matematičkih pojmova.' In Savremeni trenutak književnosti za decu u nastavi i nauci, edited by M. Janjić, 467-477. Vranje: Učiteljski fakultet.

Purpura, J. D., E. L. Hume, M. D. Sims, and J. C. Lonigan. 2011. 'Early Literacy and Early Numeracy: The Value of Including Early Literacy Skills in the Predic- 
tion of Numeracy Development.' Journal of Experimental Child Psychology 110 (4): 647-658.

Rosen, D., and J. Hoffman. 2009. 'Integrating Concrete and Virtual Manipulatives in Early Childhood Mathematics.' Young Children 64:26-33.

Skoumpourdi, C., and I. Mpakopoulou. 2011. 'The Prints: A Picture Book for PreFormal Geometry.' Early Childhood Education Journal 39:197-206.

Stakić, M. 2014. 'The Specifics of Children's Literature in the Context of Genre Classification.' Mediterranean Journal of Social Sciences 5 (19): 243-252.

Stakić, M., and S. Maričić. 2018. 'Poezija Dragana Lukića kao integrativni element razvoja govora i matematičkih pojmova u predškolskom vaspitanju i obrazovanju.' In Književnost za decu u nauci i nastavi, edited by V. Jovanović and B. Ilić, 369-385. Jagodina: Fakultet pedagoških nauka.

Stakić, M., and S. Maričić. 2019. 'Integration of Activities of Mathematical Education and Language Development in Preschool Education.' In Implicit Pedagogy for Optimized Learning in Contemporary Education, edited by J. Vodopivec, L. Jančec and T. Štemberger, 184-204. Hershey, PA: IGI Global.

Van den Heuvel-Panhuizen, M., and I. Elia. 2011. 'Kindergartners' Performance in Length Measurement and the Effect of Picture Book Reading.' The International Journal on Mathematics Education 43 (5): 621-635.

Van den Heuvel-Panhuizen, M., I. Elia, and A. Robitzsch. 2016. 'Effects of Reading Picture Books on Kindergartners' Mathematics Performance.' Educational Psychology 36 (2): 323-346.

Vigotski, L. 1977. Mišljenje i govor. Beograd: Nolit.

Wikholm, M., and J. Aerila. 2016. 'Teaching Mathematics with Children's Literature in Finland.' International Journal of Learning and Teaching 8 (4): 253261.

Welsh, J. A., R. L. Nix, C. Blair, K. L. Bierman, and K. E. Nelson. 2010. 'The Development of Cognitive Skills and Gains in Academic School Readiness for Children from Low-Income Families.' Journal of Educational Psychology 102 (1): 43-53.

Wiburne, J. M., and J. Napoli. 2008. 'Connecting Mathematics and Literature: An Analysis of Preservice Elementary School Teachers' Changing Beliefs and Knowledge.' IUMPST: The Journal 2:1-10.

Whitin, J. D., and S. Wilde. 1992. Read Any Good Math Lately? Children's Books for Mathematical Learning, K-6. Portsmouth, $\mathrm{NH}$ : Heinemann.

\section{Učenje matematike in jezika s pomočjo integrativnega pristopa v predšolskem izobraževanju}

V prispevku avtorji trdijo, da je za predšolsko izobraževanje potreben celosten pristop k učenju, v katerem so integrirana različna področja znanja. $V$ tem kontekstu je posebna pozornost namenjena pomenu vključevanja jezikovnega razvoja in izobraževanja predšolske matematike s pomočjo vsebin iz literature 
za otroke. V raziskovalnem delu so si avtorji zastavili cilj, da preučijo, v kolikšni meri izobraževalci integrirajo razvoj jezika in razvoj matematičnih pojmov, ki jih večinoma uporablja literarna oblika kot sestavni element literarnega dela, in koliko je vključevanje vključeno v vsako od področij izobraževanja predšolske matematike. Dobljeni rezultati kažejo, da vzgojitelji v delu večinoma povezujejo dejavnosti jezikovnega razvoja in matematike kot integrativnega elementa, večinoma $z$ uporabo proze in poetičnega besedila, ter da se otroška književnost večinoma uporablja kot podpora, ko je potrebno razviti pojem števila in koncepta množice.

Ključne besede: predšolska vzgoja, integracija, matematična vzgoja, jezikovni razvoj, otrok 